\title{
MEDIA INFORMASI PEMANFAATAN DAUN KERING SEBAGAI BAHAN PEMBUATAN KERAJINAN TANGAN
}

\author{
Ni Ketut Kertiasih \\ Ni Made Indah Yunitha \\ Jurusan Manajemen Informatika, FTK, Undiksha
}

\begin{abstract}
Abstrak
Ada beberapa daun kering yang dapat dimanfaatkan sebagai bahan untuk membuat kerajinan tangan. Untuk memberikan informasi pemanfaatan daun kering sebagai bahan dasar pembuatan kerajinan tangan diperlukan sebuah media informasi. Berdasarkan hal tersebut, maka dikembangkan media informasi pembuatan kerajinan tangan dengan bahan dasar daun kering. Media informasi ini berisi informasi peralatan dan bahan yang dapat digunakan, proses pengeringan bahan, proses pembuatan kerajinan, dan beberapa contoh hasil kerajinan dengan bahan daun kering. Media informasi ini dikembangkan menggunakan software umum yaitu Macromedia Flash. Melalui media informasi ini diharapkan dapat membantu memberikan informasi kepada masyarakat pada umumnya, sehingga masyarakat dapat memiliki keterampilan membuat kerajinan tangan dengan bahan daun kering. Keterampilan tersebut nantinya dapat dikembangkan untuk membentuk sebuah usaha rumah tangga maupun usaha kecil menengah.
\end{abstract}

Kata Kunci: media informasi, kerajinan tangan, daun kering.

\begin{abstract}
There were few dry leaves that can be used as materials for making handicrafts. To provide information on utilization of dry leaves in the manufacture of handicrafts needed a medium of information. Based on this, then developed an interactive information media crafts with the basic ingredients of dried leaves. This information media contains information on equipment and materials that can be used, the drying process the material, the process of making crafts, and some examples of the crafts with dried leaf material. This information media was developed using Macromedia Flash software that is common. Through this information media is expected to help provide information to the public at large, so that people can have the skills to make crafts with dried leaf material. These skills can later be developed to form a household business and small and medium businesses.
\end{abstract}

Key Words: information media, handicrafts, dried leaves 


\section{PENDAhuluan}

Dewasa ini jumlah pengangguran semakin meningkat di masyarakat. Oleh karena itu dibutuhkan cukup banyak lapangan pekerjaan untuk bisa mengatasi permasalahan pengangguran tersebut. Selain dengan disediakannya lapangan pekerjaan, juga dibutuhkan pelatihan keterampilan. Dengan bekal keterampilan yang dimiliki, setidaknya dapat membuka peluang terbentuknya UKM (Usaha Kecil Menengah) dengan modal secukupnya.

Usaha kecil menengah merupakan bagian integral dari dunia usaha nasional yang mempunyai kedudukan, potensi dan peranan yang sangat strategis dalam mewujudkan tujuan pembangunan nasional. Mengingat peranannya dalam pembangunan, usaha kecil menengah harus terus dikembangkan dengan semangat kekeluargaan, saling isi mengisi, saling memperkuat antara usaha yang kecil dan besar dalam rangka pemerataan serta mewujudkan kemakmuran bagi seluruh masyarakat. Untuk mewujudkan tujuan tersebut, pemerintah dan masyarakat harus saling bekerjasama. Masyarakat sebagai pelaku utama pembangunan, sedangkan pemerintah berkewajiban untuk mengarahkan, membimbing, melindungi serta menumbuhkan iklim usaha. Tetapi jika dilihat dari kenyataan yang ada, pada dasarnya masih banyak masyarakat yang kurang mampu atau yang berpengangguran belum mendapatkan keterampilan untuk dapat dijadikan bekal dalam mendirikan sebuah usaha kecil menengah.

Pembuatan album foto, buku catatan, yang berbahan dasar daun kering merupakan salah satu contoh kerajinan tangan yang dapat dikembangkan sebagai usaha kecil menengah. Pembuatannya pun tidak terlalu sulit, dan juga sedikit menghabiskan biaya untuk bahan dasarnya, karena hanya menggunakan daun yang dikeringkan dan batang-batang kayu yang tidak digunakan lagi. Keunikan dari produk tersebut nantinya dapat menarik perhatian dari wisatawan domestik maupun mancanegara. Sehingga penghasilan dari produk tersebut setidaknya dapat membantu perekonomian mereka.

Banyak limbah yang dimanfaatkan sebagai bahan untuk membuat kerajinan. Salah satu limbah yang dapat diigunakan adalah daun kering. Agar dapat mengolah daun kering tersebut menjadi produk kerajinan tangan, diperlukan suatu keterampilan. 
Untuk membantu masyarakat memiliki keterampilan yang nantinya dapat dikembangkan dalam usaha kecil menengah seperti membuat album foto dan buku catatan dengan menggunakan bahan dari daun kering, maka dikembangkan sebuah media informasi yang dapat digunakan sebagai media dalam memberikan informasi tentang cara pemanfaatan daun kering sebagai bahan kerajinan tangan. Media ini diharapkan dapat membantu masyarakat untuk mempunyai keterampilan mengolah daun kering menjadi sebuah kerajinan tangan. Keterampilan ini sebagai bekal agar nantinya dikembangkan menjadi usaha kecil menengah dengan memadukan media visualisasi dan simulasi secara digital.

\section{PEMBAHASAN}

\subsection{Kerajinan Tangan dengan Bahan Dasar Daun Kering}

Kerajinan tangan dari daun merupakan proses kerajinan tangan yang memanfaatkan daun sebagai sarana kerajinan hingga membentuk ornamen seni yang indah dan penuh makna. Tujuannya adalah untuk mengurangi sampah daun, memanfaatkan dan memproses daun menjadi kreasi seni kerajinan tangan dari daun (Jauhari, 2007). Contoh daun yang biasa digunakan pada kerajinan tangan ini adalah daun Waru, daun Sekapa, daun Lamtoro, dan pelepah pisang. Bahan pelengkap yang lain juga bisa digunakan tergantung motif yang ingin dibuat. Hasil dari kerajinan tangan ini seperti album foto dan buku catatan. Kerajinan tangan dengan bahan dasar daun kering ini sangat diminati di mancanegara. Sehingga kebanyakan pemesan berasal dari luar negeri.

\subsection{Jenis-jenis Kerajinan Tangan dengan Bahan Dasar Daun Kering}

Banyak jenis kerajinan yang dapat dihasilkan dengan memanfaatkan daun kering. Diantaranya adalah album foto, buku catatan, dan sebagainya. Masing-masing jenis kerajinan tangan yang terbuat dari daun kering memiliki beberapa motif.

1. Motif album foto

Motif dari album foto adalah sebagai berikut.

a. Album foto dengan motif bintang

b. Album foto dengan motif kura-kura 
c. Album foto dengan motif kupu-kupu

2. Motif buku catatan

Motif dari buku catatan adalah sebagai berikut.

a. motif polos

b. motif pantai

\subsection{Bahan dan Alat yang Digunakan dalam Pembuatan Kerajinan Tangan Berbahan Dasar Daun Kering}

Pada pembuatan kerajinan tangan dengan bahan dasar daun kering ada beberapa bahan dan alat yang digunakan secara umum untuk membentuk kerajinan tangan itu sendiri dan pemberian motifnya. Bahan dan alatnya sebagai berikut.

1. Bahan

Bahan yang digunakan dalam pembuatan kerajinan tangan ini adalah daun kering dan beberapa bahan lainnya yang akan dijelaskan sebagai berikut.
a. Kulit Lamtoro
b. Daun Waru
c. Pelepah Pisang
d. Tali
e. Tali
f. Kertas Manila
g. Kertas Karton
h. Kardus
i. Lem
j. Cat Vernis

2. Alat

Alat yang digunakan untuk membuat kerajinan tangan dengan bahan dasar daun kering adalah bor mesin, jarum, gunting, kuas, penggaris. 


\subsection{Proses Pembuatan Kerajinan Tangan dengan Bahan Dasar Daun Kering}

Ada tiga tahap dalam proses pembuatan kerajinan tangan dengan bahan dasar daun kering. Yaitu tahap pembuatan motif, pembuatan lembaran atau isi dan tahap pengecatan.

Beberapa tahapan pada proses pembuatan kerajinan tangan, yaitu sebagai berikut.

1. Tahap Pembuatan Motif

Tahap yang pertama secara umum pada proses pembuatan kerajinan tangan memiliki cara pembuatan yang hampir sama yaitu pembuatan motif. yang membedakan hanya dari segi bahan yang digunakan.

\section{Tahap Pembuatan Lembaran}

Untuk membuat lembaran disesuaikan dengan ketebalan atau berapa lembar yang akan dibuat. Tali gubal dipasang pada lembaran, disetiap lembaran disatukan dengan kertas Dursla untuk bisa membedakan halaman foto. Setelah proses pembuatan lembaran selesai maka lembaran ditempelkan pada bagian depan dan belakang yang sudah disatukan lebih awal menggunakan lem Fox.

\section{Tahap Pengecatan}

Untuk menyempurnakan pembuatan kerajinan tangan tersebut maka diperlukannya tahap pengecatan. Tahap ini merupakan tahap pengolesan bahan menggunakan pernis agar menjadi lebih mengkilat. Tujuannya agar bahan bisa menjadi tahan lama dan terlihat lebih indah.

\subsection{Hasil Pengembangan Media Informasi Proses Pembuatan Kerajinan}

Pengembangan media informasi proses pembuatan kerajinan tangan dikembangkan dengan menggunakan software umum yaitu Macromedia Flash. Media informasi ini berisi tuntunan langkah demi langkah proses pengolahan daun kering menjadi sebuah kerajinan tangan. Informasi yang terdapat pada media informasi ini adalah contoh-contoh kerajinan tangan yang dihasilkan dengan memanfaatkan daun 
kering sebagai bahan dasarnya yang dapat dilihat pada menu galeri. Disamping itu, juga terdapat informasi tentang alat dan bahan yang digunakan dalam membuat kerajinan, proses pengeringan, dan proses pembuatan.

Adapun informasi-informasi yang terdapat pada media informasi meliputi:

\section{Alat dan Bahan}

Informasi ini berisi informasi tentang alat dan bahan yang digunakan untuk membuat kerajinan. Gambar tampilan alat dan bahan seperti terlihat pada Gambar 1.

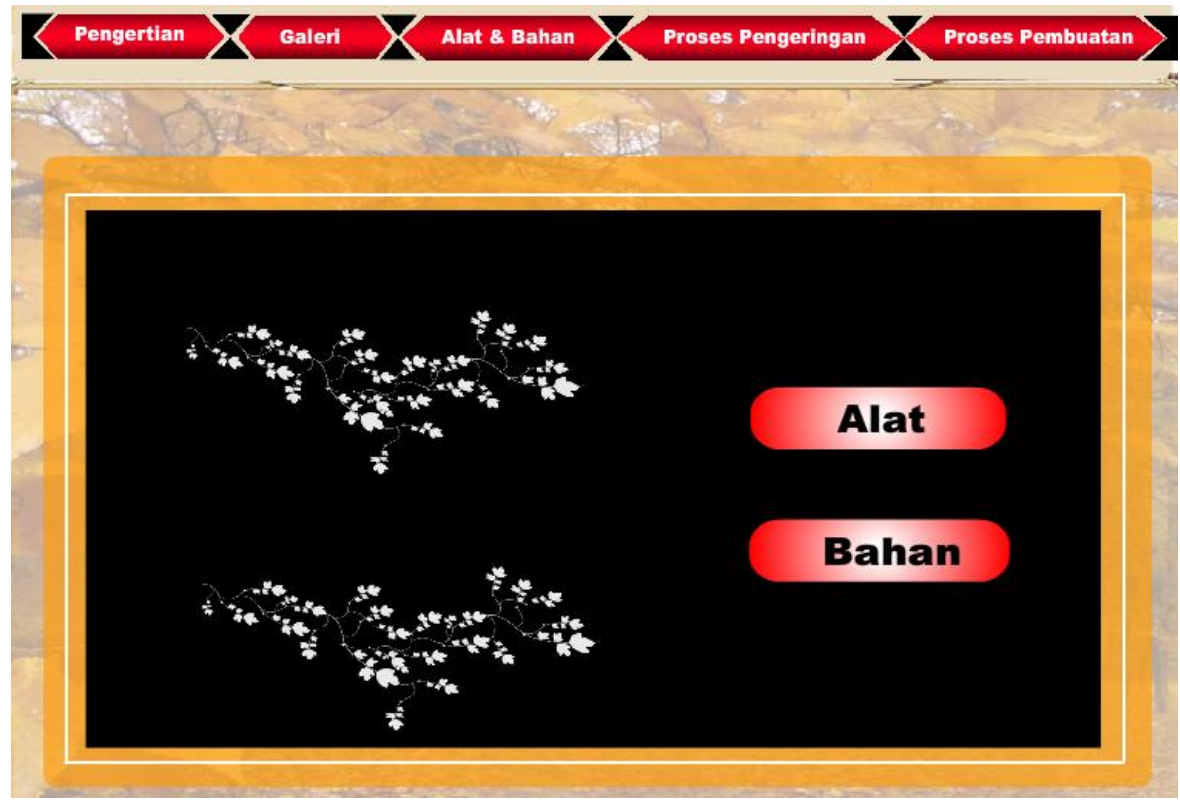

Gambar 1. Tampilan Menu Alat dan Bahan

2. Proses Pengeringan Daun

Pada proses pengeringan ini berisi informasi tentang proses pengeringan daun. Adapun tampilan menu proses pengeringan daun seperti terlihat pada Gambar 2. 


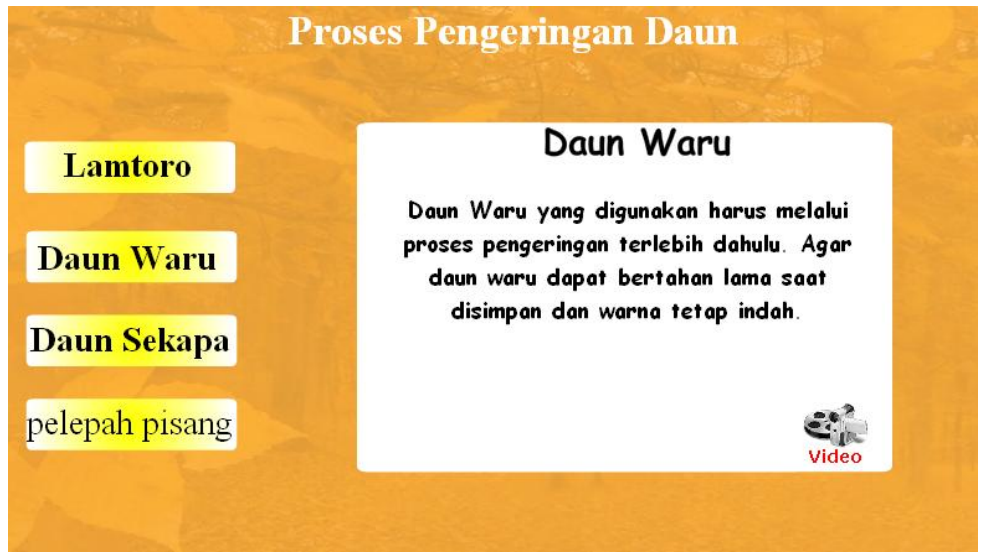

Gambar 2. Tampilan Menu Proses Pengeringan Daun

3. Proses Pembuatan

Pada proses pembuatan ini berisi informasi tentang proses pembuatan kerajinan tangan dengan bahan daun kering. Adapun tampilan menu proses pembuatan kerajinan seperti terlihat pada Gambar 3.

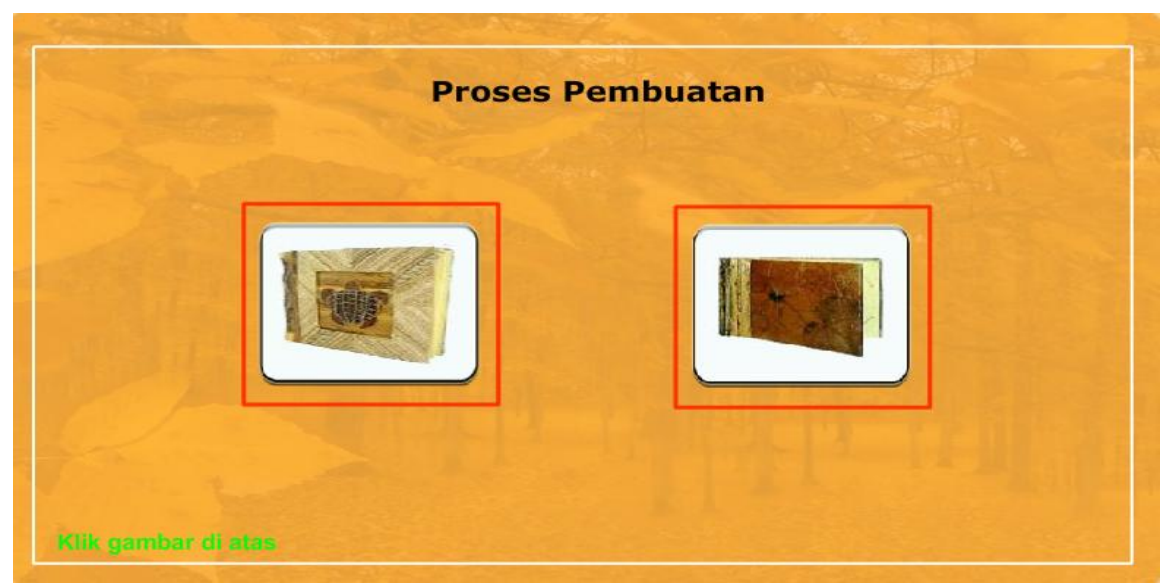

Gambar 3. Tampilan Menu Proses Pembuatan Kerajinan

\section{Produk Kerajinan}

Pada bagian ini berisi informasi tentang kerajinan-kerajinan yang dapat dihasilkan dengan memanfaatkan daun kering sebagai bahannya. Adapun tampilan menu produk kerajinan seperti terlihat pada Gambar 4. 


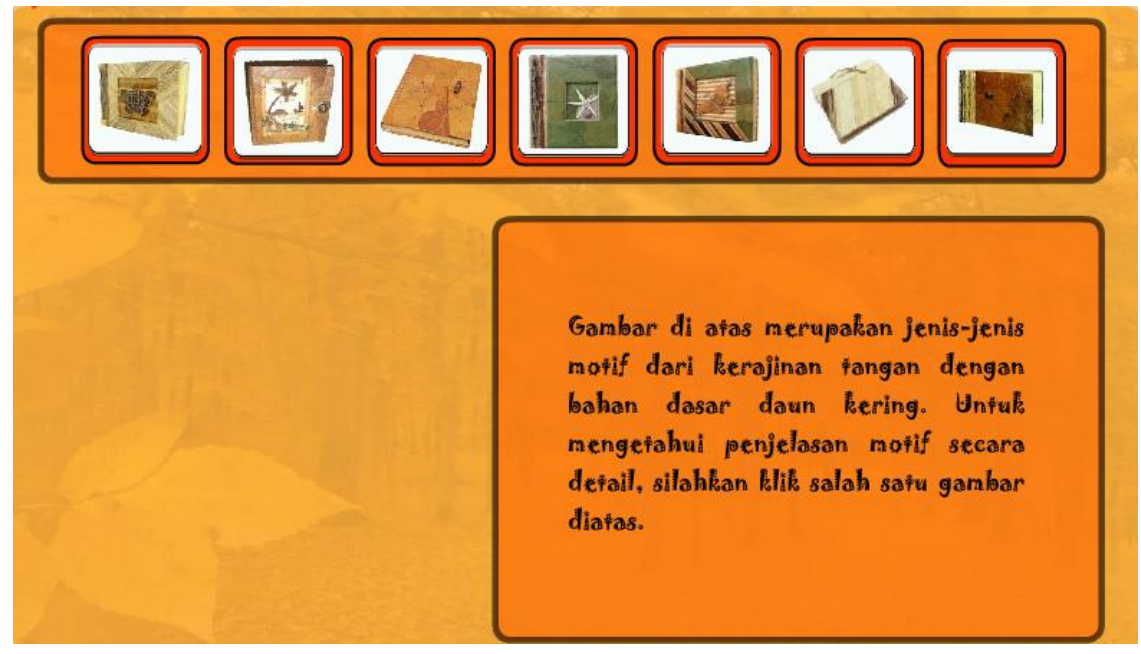

Gambar 3. Tampilan Menu Produk Kerajinan

\section{PENUTUP}

Media informasi pembuatan kerajinan tangan dengan bahan dasar daun kering ini dikembangkan menggunakan Macromedia Flash 8. Media informasi ini dapat dijadikan sebagai media untuk menginformasikan proses pembuatan kerajinan tangan dengan bahan dasar daun kering. Informasi yang terdapat pada media ini meliputi alat dan bahan yang digunakan untuk membuat kerajinan, proses pengeringan daun, dan proses pembuatan kerajinan tangan ini, serta beberapa contoh kerajinan yang telah dihasilkan. Pengembangan media informasi ini diharapkan dapat menambah keterampilan membuat kerajinan tangan dengan memanfaatkan daun kering sebagai bahannya.

\section{DAFTAR PUSTAKA}

Anonim. 2009. “Kerajinan”, tersedia pada http://id.wikipedia.org/wiki/kerajinan.

Hartono, Rudi. "Kreasi Mendaur Ulang Sampah". Tersedia pada http://www.pwec.com/content/id/go_green/kreasi-mendaur-ulang-sampah.pdf

Jauhari, Nurudin. 2007. "Seni Kerajinan Tangan dari Daun", tersedia pada http://senidaun.blogdetik.com.

Sudrajat, Akhmad. 2008. "Media Pembelajaran", tersedia pada http://Blog.WordPress.com.

JPTK, UNDIKSHA, Vol. 7, No. 1, Januari 2010 : 13 - 20 